\title{
Water Discharge Management Based on Open and Closed Cylinders in the Gravitation Water Vortex Power Plant
}

\section{Pengaturan Debit Air Berbasis Basin Silinder Terbuka Dan Tertutup Pada Alat Gravitation Water Vortex Power Plant}

\author{
Ainun Nasuki ${ }^{1)}$, Muhammad Hasan Basri ${ }^{2)}$ \\ ${ }^{1,2)}$ Departement Electrical Engineering, Faculty Engineering, Nurul Jadid University Probolinggo, Indonesia \\ 1) redifanani@gmail.com \\ ${ }^{2}$ hasanmohammadbasri83@gmail.com
}

\begin{abstract}
A Gravitation Water Vortex Power Plant (GWVPP) tool has been made to determine how much water flow is needed to generate electricity. This research was conducted by changing the flow rate and water pressure to determine the effect on the performance of a vortex power plant, and in previous studies, no one has made changes to the discharge and water pressure. The type of basin position used in this study is an open basin position and a closed basin position. Based on the advantages and disadvantages of each type of blade used, a study was carried out using the type of turbine blade model L by changing the water flow rate and water pressure at a predetermined position to determine the effect of water discharge and pressure on the turbine rotational speed. From the results of testing the water discharge measurement in a closed basin which is carried out on the addition of each flow of water discharge at the angle of the faucet 00 to $90 \mathrm{o}$ with a volume (V) $98 \mathrm{~L}$ and time (t) 1.11 minutes to 2.5 minutes, it can be seen that the average discharge value (Q) the resulting $81.081 / \mathrm{s}$. and from the results of testing the water discharge measurement in the open basin which is carried out to the addition of each flow of water discharge at the angle of the faucet 00 to $90 \mathrm{o}$ with a volume (V) $98 \mathrm{~L}$ and time (t) 1.28 minutes to 4.1 minutes it can be seen that the average discharge value $(\mathrm{Q})$ resulting in $65.211 / \mathrm{s}$.
\end{abstract}

Keywords: Gravitation Water Vortex Power Pland;Turbine; Debit.

Abstrak.- Telah dibuat alat Gravitation Water Vortex Power Plant (GWVPP) untuk mengetahui berapa debit air yang dibutuhkan untuk menghasilkan listrik. Penelitian ini dilakukan dengan melakukan perubahan debit dan tekanan air untuk mengetahui pengaruhnya terhadap kinerja dari sebuah pembangkit listrik tenaga pusaran air (vortex), dan pada penelitianpenelitian sebelumnya masih belum ada yang melakukan perubahan debit dan tekanan air. Jenis posisi basin yang digunakan pada penelitian ini adalah posisi basin terbuka, dan posisi basin tertutup. Berdasarkan kelebihan dan kekurangan masing-masing jenis sudu yang digunakan maka dilakukan penelitian menggunakan jenis sudu turbin model L dengan melakukan perubahan debit air dan tekanan air pada posisi yang telah ditentukan untuk mengetahui pengaruh debit dan tekanan air terhadap kecepatan putar turbin. Dari hasil pengujian pengukuran debit air pada basin tertutup yang dilakukan terhadap penambahan setiap aliran debit air pada sudut kran $0^{\circ}$ sampai $90^{\circ}$ dengan volume (V) $98 \mathrm{~L}$ dan waktu (t) 1.11 menit sampai 2.5 menit dapat diketahui nilai rata-rata debit $(\mathrm{Q})$ yang dihasilkan $81.08 \mathrm{l} / \mathrm{s}$. dan dari hasil pengujian pengukuran debit air pada basin terbuka yang dilakukan terhadap penambahan setiap aliran debit air pada sudut kran $0^{\circ}$ sampai $90^{\circ}$ dengan volume $(\mathrm{V}) 98 \mathrm{~L}$ dan waktu $(\mathrm{t})$ 1.28 menit sampai 4.1 menit dapat diketahui nilai rata-rata debit $(\mathrm{Q})$ yang dihasilkan $65.21 \mathrm{l} / \mathrm{s}$.

Kata Kunci: Pembangkit Listrik Vortex Air Gravitasi; Turbin; Pembuangan. 


\section{PENDAHULUAN}

Indonesia memiliki potensi sumber daya energi baru terbarukan (EBT) yang yang belum dimanfaatkan sepenuhnya. Pemanfaatan energi baru terbarukan mendapat dukungan pemerintah dengan adanya kebijakan dan peraturan terkait dengan pengembangan dan pemanfaatan energi baru dan terbarukan, diantaranya adalah UU No. 30 tahun 2007 tentang energi yang memprioritaskan penyediaan dan pemanfaatan energi baru dan terbarukan. Pemerintah menerbitkan Peraturan Pemerintah No. 3 tahun 2005 tentang perubahan atas Peraturan Pemerintah No. 10 tahun 1989 tentang penyediaan dan pemanfaatan tenaga listrik yang menyatakan bahwa guna menjamin ketersediaan energi primer untuk kepentingan umum, diprioritaskan sumber energi setempat dengan kewajiban mengutamakan pemanfaatan sumber energi terbarukan [1].

Air merupakan salah satu sumber daya alam yang tidak terbatas jumlah nya. Air juga memiliki potensi yang sangat besar dan dapat digunakan sebagai sumber energy yang bersih karena tidak menghasilkan polutan. Selain itu air juga tidak mempunyai potensi merusak ozon maupun potensi pemanasan global. Energi air adalah salah satu sumber energi terbarukan yang berasal dari aliran air yang dimanfaatkan untuk menghasilkan energi listrik dengan cara menggunakan aliran air yang mengalir untuk memutar turbin, selanjutnya turbin dihubungkan dengan generator. Generator yang berputar akan mengubah energi putar hingga menghasilkan energi listrik [2].Teknologi energi terbarukan memberikan harapan besar sebagai alternatif yang bebas polusi untuk menggantikan instalasi tenaga berbahan bakar nuklir dan fosil untuk memenuhi kebutuhan energi listrik [3].

Penelitian ini dilakukan dengan melakukan perubahan debit dan tekanan air untuk mengetahui pengaruhnya terhadap kinerja dari sebuah pembangkit listrik tenaga pusaran air, dan pada penelitian-penelitian sebelumnya masih belum ada yang melakukan perubahan debit dan tekanan air. Jenis-jenis posisi basin yang digunakan pada penelitian ini adalah posisi basin terbuka, dan posisi basin tertutup. Berdasarkan kelebihan dan kekurangan masingmasing jenis sudu yang digunakan maka dilakukan penelitian menggunakan dua jenis sudu turbin yang berbeda dengan melakukan perubahan debit air dan tekanan air pada posisi yang telah ditentukan untuk mengetahui pengaruh debit dan tekanan air terhadap kecepatan putar turbin dan generator serta tegangan dan arus keluaran dari generator.

Dari latar belakang di atas penelitian ini bertujuan untuk pengaturan debit air berbasis basin silinder terbuka dan tertutup pada alat gravitational water vortex power plant berbasis basin silinder.

\section{LANDASAN TEORI}

Teori yang digunakan untuk penunjang dalam menyelesaikan penelitian ini, diantaranya :

\subsection{Teori Dasar Aliran}

Air yang mengalir mempunyai energi yang dapat digunakan untuk memutar roda turbin, karena itu pusat-pusat tenaga air dibangun di sungai- sungai dan di pegununguanpegunungan. Pusat tenaga air tersebut dapat dibedakan dalam 2 golongan, yaitu pusat tenaga air tekanan tinggi dan pusat tenaga air tekanan rendah. Kaidah energi menyatakan bahwa suatu energi akan dapat diubah menjadi bentuk energi lain. Arus air yang mengandung energi dan energi tersebut dapat diubah bentuknya, misalnya perubahan dari energi potensial (tekanan) ke dalam energi kinetis (kecepatan), atau sebaliknya. Artinya selanjutnya dari kaidah kekekalan energi adalah apabila arus air dalam alirannya dilewatkan melalui turbin air, maka energi yang ada dalam air akan diubah menjadi bentuk energi yang lain [4].

\subsection{Aliran Vortex}

Vortex adalah massa fluida yang partikel-partikelnya bergerak berputar dengan garis arus (streamline) membentuk lingkaran konsentris. Gerakan vortex berputar disebabkan oleh adanya perbedaan antara lapisan fluida yang berdekatan. Dapat diartikan juga sebagai gerak fluida yang diakibakan oleh parameter kecepatan dan tekanan. Vortex sebagai pusaran yang merupakan efek dari putaran rotasional dimana viskositas berpengaruh didalamnya [5]. Seperti pada gambar 1.

[Figure 1 about here.]

\subsection{Gravitation Water Vortex Power Plan (GWVPP)}

Gravitational Water Vortex Power Plant adalah jenis green technology yang termasuk dalam kategori pembangkit listrik tenaga mikrohidro. Pada pembakit ini berbasis basin silinder sebagai lubang masuk (inlet) yang besar dan lurus, yang kemudian mengalir secara tangensial ke cekungan bundar. Air kemudian akan membentuk pusaran yang kuat, yang keluar dari saluaran keluar (outlet) di bagian tengah bawah basin [6].

[Figure 2 about here.]

\subsection{Turbin Model L}

Turbin adalah bagian terpenting dari pembangkit listrik. Pada turbin aliran air diubah menjadi energi kinetik yang akan memutar rotor. Dengan belt, puli ataupun gearbox pada rotor dihubungkan dengan generator yang akan mengubah putaran yang dihasilkan menjadi energi listrik [7].

[Figure 3 about here.] 


\subsection{Basin Silinder}

Wadah (basin) atau tempat penampung air yang nantinya akan terjadi pembentukan vortex ini. Tes eksperimental telah dilakukan untuk membandingkan kinerja sistem basin berbentuk kerucut dengan sistem basin silinder. Karena peningkatan nilai velocity head dengan peningkatan kedalaman dan kekuatan vortex yang lebih besar, efisiensi turbin lebih besar di basin berbentuk kerucut dibandingkan dengan silinder silinder. Geometri basin tergantung pada debit yang disediakan. Di bawah kondisi aliran yang memadai, diameter minimum vortex berada di tingkat bawah dan selalu lebih kecil dari lubang keluar. Adapun model basin ada 2, yaitu basin kerucut dan basin silinder [8].

[Figure 4 about here.]

\subsection{Generator 3 Phase}

Generator adalah pengkonversi energi dari bentuk energi mekanik menjadi energi listrik yang berlangsung di daerah medan magnet . generator fluks aksial magnet permanen 3 phasa. Stator dibentuk dengan jumlah kumparan sebanyak 9 kumparan terdiri dari 1000 lilitan per kumparan sedangkan rotor menggunakan magnet sebanyak 24 buah setiap rotornya. Tegangan induksi DC tiga phasa yang digunakan pada alat gravitation water vortex power plant [9].

[Figure 5 about here.]

\section{METODELOGI PENELITIAN}

\subsection{Diagram Alur Penelitian}

Penelitian ini dilaksanakan dengan mengikuti tahaptahap seperti pada diagram alur (Flowchart )berikut ini:

[Figure 6 about here.]

\subsection{Perancangan Alat Gravitation Water Vortex Power Plant}

Dari perancangan basin dan turbin yang telah dilakukan pada tahap penelitian sebelumnya, pada tahap ini dilakukan pengerjaan terhadap pembuatan alat Gravitation Water Vortex Power Plant (GWVPP), seperti yang ditunjukkan pada gambar 7.

[Figure 7 about here.]

Rancangan alat dari GWVPP ini dengan bahan dasar dari alat ini adalah besi berbentuk L sebagai penyangga basin GWVPP dan segala komponen lainnya. Komponen utama dari rancang bangun GWVPP ini adalah basin GWVPP dan Gearbox yang terdapat pada kerangkan alat.

\section{Proses Pengujian}

Pengujian alat dilakukan dengan cara mengalirkan air dengan pompa air yang menghasilkan debit air 95 liter/menit ke dalam penampungan air. Dengan menggunakan diameter outlet basin $3 \mathrm{~cm}$, dapat terbentuk fenomena vortex seperti pada Gambar 8.

[Figure 8 about here.]

\subsection{Proses Pengambilan Data}

Setelah alat telah selesai dibuat, dimulailah pengambilan data dengan pemberian debit air 96 liter/menit dan variasi kedalaman turbin terhadap basin yaitu $50 \mathrm{~cm}, 25 \mathrm{~cm}$, dan 10 $\mathrm{cm}$. serta variasi jumlah sudu yaitu 4. Data yang diambil berupa:

\section{1). Pengambilan Data Debit Air Basin Tertutup}

Pengambilan data pada debit air basin tertutup di lakukan untuk mengetahui seberapa besar air yang dibutuhkan untuk mengisi tabung basin silinder pada alat vortex agar bisa terjadi nya fenomena pusaran air untuk dijadikan aliran listrik. Fenomena pusaran air dapat dilihat pada gambar di bawah :

[Figure 9 about here.]

2). Pengambilan Data Debit Air Basin Terbuka

Pengambilan data pada debit air basin terbuka di lakukan untuk mengetahui pada ketinggian berapa terjadinya vortex, Fenomena pusaran air dapat dilihat pada gambar di bawah :

[Figure 10 about here.]

\subsection{Proses Analisa Data}

Dari pengukuran yang dilakukan dapat diketahui berapa debit air yang dibutuhkan pada basin silinder pada alat GWVPP untuk mengetahui terjadinya fenomena vortex, pada waktu Basin Tertutup dan Basin Terbuka. Dengan menggunakan persamaan :

$$
Q=\frac{V}{t}
$$

dimana:

$$
\begin{aligned}
& Q=\text { Debit }\left(\mathrm{m}^{3} / \mathrm{s}\right) \\
& V=\text { Volume wadah }\left(\mathrm{m}^{3}\right) \\
& t=\text { waktu yang dibutuhkan untuk memenuhi wadah (s) }
\end{aligned}
$$

Beberapa parameter yang diukur adalah tampang lintang sungai, elevasi muka air, dan kecepatan aliran [10]. Selanjutnya, debit aliran dihitung dengan mengalikan luas penampang dan kecepatan aliran. 


\section{HASIL DAN PEMBAHASAN}

5.1 Hasil dan Pembahasan Pengujian Data Debit Air Basin Tertutup

Hasil dari pengujian debit air basin tertutup yang dilakukan terhadap penambahan setiap aliran debit air pada sudut kran $0^{\circ}$ sampai $90^{\circ}$ dengan melakukan 10 pengujian maka didapatkan hasil yang dapat dilihat pada tabel 1. Cara menghitung aliran debit air dengan bukaan kran $0^{\circ}$ dengan basin ukuran 98 liter dan isi penuh memerlukan waktu 1.11 menit, sebagai berikut :

$$
Q=\frac{98}{1.11}=88.28 \mathrm{l} / \mathrm{s}
$$

Hasil perhitungan tersebut dapat dilihat pada tabel di bawah ini.

\section{[Table 1 about here.]}

Debit terbesar dengan nilai 89.09 1/s di uji coba dengan bukaan katup gas pompa air $10^{\circ}$. Lebih jelasnya tertera pada grafik 11.

[Figure 11 about here.]

Dari pengujian pengukuran debit air pada basin tertutup yang dilakukan terhadap penambahan setiap aliran debit air pada sudut kran $0^{\circ}$ sampai $90^{\circ}$ dengan volume (V) $98 \mathrm{~L}$ dan waktu (t) 1.11 menit sampai 2.5 menit dapat diketahui nilai rata-rata debit $(\mathrm{Q})$ yang dihasilkan $81.08 \mathrm{l} / \mathrm{s}$, dapat dilihat pada table di bawah ini :

[Table 2 about here.]

Pada Hasil pengujian rata-rata tabel 2 pengukuran debit air basin tertutup dengan wadah basin silinder ukuran 96 liter dan isi penuh memerlukan waktu rata-rata $81.08 \mathrm{l} / \mathrm{s}$, maka dapat dilihat terjadinya nya fenomena pusaran air (vortex) pada saat debit air (Q) 64,47 l pada waktu $(t)$ 1,52 menit dengan bukaan kraan $70^{\circ}$ saat basin tetrtutup.

Maka dapat disimpulkan bahwa terjadinya fenomena pusaran air dengan wadah basin silinder ukuran diameter 50 $\mathrm{cm}$ dan tinggi $60 \mathrm{~cm}$ dan wadah ukur 96 liter sebagai rumah turbin, dapat dilihat fenomena vortex pada saat waktu $(t) 1,52$ menit, yang dapat menggerakkan turbin untuk dapat menghasilkan listrik.

\subsection{Hasil dan Pembahasan Pengujian Data Debit Air Basin Terbuka}

Hasil dari pengujian debit air basin terbuka yang dilakukan terhadap penambahan setiap aliran debit air pada sudut kran $0^{\circ}$ sampai $90^{\circ}$ dengan melakukan 10 pengujian maka didapatkan hasil yang dapat dilihat pada tabel 1. Cara menghitung aliran debit air dengan bukaan kran $0^{\circ}$ dengan basin ukuran 98 liter dan isi penuh memerlukan waktu 1.28 menit, sebagai berikut :

$$
Q=\frac{98}{1.28}=76.56 l / s
$$

10.21070/jeeeu.v5i1.1008

Hasil perhitungan tersebut dapat dilihat pada tabel di bawah ini.

$$
\text { [Table } 3 \text { about here.] }
$$

Debit terbesar dengan nilai $76.56 \mathrm{l} / \mathrm{s}$ di uji coba dengan bukaan katup gas pompa air $0^{\circ}$. Lebih jelasnya tertera pada gambar 11 .

[Figure 12 about here.]

Dari pengujian pengukuran debit air pada basin terbuka yang dilakukan terhadap penambahan setiap aliran debit air pada sudut kran $0^{\circ}$ sampai $90^{\circ}$ dengan volume (V) $98 \mathrm{~L}$ dan waktu (t) 1.28 menit sampai 4.1 menit dapat diketahui nilai rata-rata debit $(\mathrm{Q})$ yang dihasilkan $65.21 \mathrm{l} / \mathrm{s}$, dapat dilihat pada table di bawah ini :

\section{[Table 4 about here.]}

Pada Hasil pengujian rata-rata tabel 4 pengukuran debit air basin tertutup dengan wadah basin silinder ukuran 96 liter dan isi penuh memerlukan waktu rata-rata $65.21 \mathrm{l} / \mathrm{s}$, maka dapat dilihat terjadinya nya fenomena pusaran air (vortex) pada saat debit air $(\mathrm{Q}) 73,68 l$ pada waktu $(t)$ 1,33 menit dengan bukaan kraan $60^{\circ}$ saat basin terbuka.

Maka dapat disimpulkan bahwa terjadinya fenomena pusaran air dengan wadah basin silinder ukuran diameter 50 $\mathrm{cm}$ dan tinggi $60 \mathrm{~cm}$ dan wadah ukur 96 liter sebagai rumah turbin, dapat dilihat fenomena vortex pada saat waktu $(t) 1,33$ menit, yang dapat menggerakkan turbin untuk dapat menghasilkan listrik.

\section{PENUTUP}

\subsection{Kesimpulan}

Setelah melakukan tahap perancangan dan pembuatan system yang kemudian dilanjutkan dengan tahap pengujian dan analisa maka dapat diambil kesimpulan sebagai berikut :

1. Telah dibuat alat Gravitation Water Vortex Power Plant (GWVPP) untuk mengetahui berapa debit air yang dibutuhkan untuk menghasilkan listrik.

2. Dari pengujian pengukuran debit air pada basin tertutup yang dilakukan terhadap penambahan setiap aliran debit air pada sudut kran $0^{\circ}$ sampai $90^{\circ}$ dengan volume (V) $98 \mathrm{~L}$ dan waktu (t) 1.11 menit sampai 2.5 menit dapat diketahui nilai rata-rata debit (Q) yang dihasilkan 81.08 1/s.

3. Dari pengujian pengukuran debit air pada basin terbuka yang dilakukan terhadap penambahan setiap aliran debit air pada sudut kran $0^{\circ}$ sampai $90^{\circ}$ dengan volume (V) $98 \mathrm{~L}$ dan waktu (t) 1.28 menit sampai 4.1 menit dapat diketahui nilai rata-rata debit $(\mathrm{Q})$ yang dihasilkan $65.21 \mathrm{l} / \mathrm{s}$. 


\subsection{Saran}

Setelah melakukan percobaan langsung dilapangan maka ada beberapa pengembangan yang dapat dilakukakan untuk penelitian selanjutnya untuk penyempurnaan alat yang telah dibuat.

1. Penelitian selanjutnya dapat menambah generator agar turbin dapat di uji sampai menghasilkan listrik, agar mengetahui daya listrik yang dapat di hasilkan oleh turbin vortex ini.

2. Bentuk rumah turbin dapat dirubah agar putaran pusaran air dapat meningkat dengan merubah dasar tabung basin silinder vortex.

3. Alat-alat ukur pengujian ditingkatkan kualitasnya dan metode ujinya ditingkatkan agar mendapatkan hasil pengujian yang valid.

\section{REFERENSI}

[1] Kementrian Energi dan Sumber Daya mineral 2017. Statistik Ketenaga listrikan 2016. Edisi nomor 30. Jakarta Jendral Ketenaga listrikan.

[2] L. Jasa. "Investigasi sudut Nozzle dan Sudut Kelengkungan Sudu Turbin Air Untuk Peningkatan Efisiensi Mikro Hidro" (Disertasi). Surabaya : Institut Teknologi Sepuluh Nopember. 2015.

[3] Muliadi, E. W. Rahayu. "Rancang Bangun Turbin Ulir Very Low Head Sebagai Pembangkit Listrik Tenaga Mikro Hidro". Media Bina Ilmiah Vol.10 No.4. ISSN:1978-3787.

[4] Made Angga, Lie Jasa, Antonius Ibi Weking. "Studi Analisis Perubahan Debit dan Tekanan Air Pada Pemodelan Pembangkit Listrik Tenaga Mikro Hidro", Majalah Ilmiah Teknologi Elektro, Vol. 17, No, 2. ISSN: 1693-2951. Universitas Udayana. 2018.

[5] Zainudin, Basuki Rahmat, 2017, "Pengujian Alat Uji Vortex Bebas Dan Vortex Paksa", Volume 8 No 3, Zona Mesin Issn 2087 - 698x.

[6] Mochammad Ilman Nafi', Muhammad Hasan Basri, Hilman Saraviyan Iskaanto, Bachtera Indarto, Alfin Tranggono Agus Salim.” Rancang Bangun Gravitation Water Vortex Power Plant (GWVPP) Berbasis Basin Silinder”. JEECAE Vol.5, No.1, Mei 2020.

[7] Muhammad Syaifuddin Zuhri, Muhammad Hasan Basri, Hilman Saraviyan Iskawanto, Bachtera Indarto.” Design of Turbine $L$ in Cylinder Basin Wall with Turbine Distance of $5 \mathrm{Cm}$ and $10 \mathrm{Cm}$ in the Effects of Electric Power on Gravitation Water Vortex Power Plant (GWVPP)". Journal of Electrical and Electronic
Engineering-UMSIDA ISSN 2460-9250 (print), ISSN 2540-8658(online)Vol. 4, No. 1, April 2020.

[8] Muhlas Budi Utomo, Muhammad Hasan Basri, dan Fuad Hasan." Eksperimen Variasi Tabung Basin Silinder Pada Gravitation Water Vortex Power Plant (GWVPP) Berbasis Basin Silinder". CYCLOTRON, Volume 3 Nomor 2, Juli 2020. P-ISSN2614-5499, EISSN2614-5164.

[9] Muhammad Bahrullah, Muhammad Hasan Basri, Amalia Herlina, Bachtera Indarto. "Perancangan Generator 3 Phase Pada Gravitation Water Vortex Power plant". Jurnal Teknik Mesin Vol.7 No.1 Juni 2020 ; pp. $46-53$.

[10] Fredi Kusuma Putra, Muhammad Hasan Basri, Tijaniyah Tijaniyah, Bachtera Indarto." The Effect Of Turbine Level Of Model L And Turbine Model S In Gravitation Of Water Vortex Plant Power (GWVPP) Based On Cylinder Basin". Journal of Electrical and Electronic Engineering-UMSIDA ISSN 2460-9250 (print), ISSN 2540-8658 (online) Vol. 4, No. 1, April 2020.

Conflict of Interest Statement: The author declares that the research was conducted in the absence of any commercial or financial relationships that could be construed as a potential conflict of interest.

Copyright () 2021 Author [s]. This is an open access article distributed under the terms of the Creative Commons Attribution License (CC BY). The use, distribution or reproduction in other forums is permitted, provided the original author(s) and the copyright owner(s) are credited and that the original publication in this journal is cited, in accordance with accepted academic practice. No use, distribution or reproduction is permitted which does not comply with these terms.

Received: 2020-10-24

Accepted: 2021-02-26

Published: 2021-03-24 
$\int \sqrt{G} \sqrt{A} \sqrt{G}\left[\int \begin{array}{l}\text { Journal of Electrical and Electronic Engineering-UMSIDA } \\ \text { ISSN 2460-9250 (print), ISSN 2540-8658 (online) }\end{array}\right.$

Vol. 5, No. 1, April 2021

\section{DAFTAR TABEL}

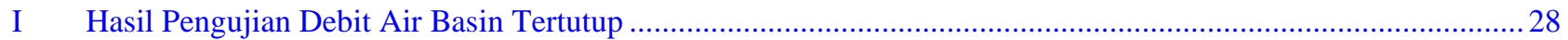

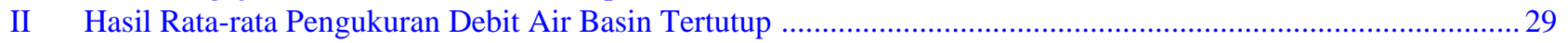

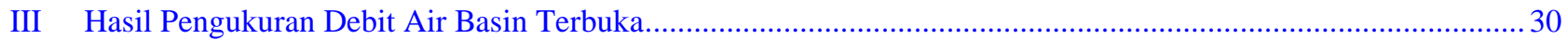

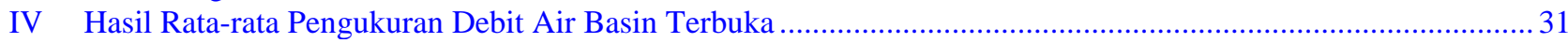


Table I. Hasil Pengukuran Debit Air Basin Tertutup

\begin{tabular}{|c|c|c|c|c|}
\hline No & $\begin{array}{c}\text { Volume } \\
(\mathbf{V})\end{array}$ & $\begin{array}{c}\text { Waktu } \\
(\mathbf{t})\end{array}$ & $\begin{array}{c}\text { Sudut Kran } \\
\left.\mathbf{(}^{\mathbf{(}}\right)\end{array}$ & Debit (Q) \\
\hline 1 & 98 liter & 1.11 & $0^{0}$ & 88.28 \\
\hline 2 & 98 liter & 1.10 & $10^{0}$ & 89.09 \\
\hline 3 & 98 liter & 1.12 & $20^{0}$ & 87.5 \\
\hline 4 & 98 liter & 1.14 & $30^{\circ}$ & 85.96 \\
\hline 5 & 98 liter & 1.22 & $40^{\circ}$ & 80.32 \\
\hline 6 & 98 liter & 1.29 & $50^{\circ}$ & 75.96 \\
\hline 7 & 98 liter & 1.40 & $60^{\circ}$ & 70 \\
\hline 8 & 98 liter & 1.52 & $70^{\circ}$ & 64.47 \\
\hline 9 & 98 liter & 2.00 & $80^{\circ}$ & 49 \\
\hline 10 & 98 liter & 2.50 & $90^{\circ}$ & 39.2 \\
\hline
\end{tabular}


Table II. Hasil Rata-rata Pengukuran Debit Air Basin Tertutup

\begin{tabular}{|c|c|}
\hline Waktu (t) & Debit (Q) \\
\hline 1.11 & 88.2 \\
\hline 1.1 & 89.09 \\
\hline 1.12 & 87.5 \\
\hline 1.14 & 85.96 \\
\hline 1.22 & 80.32 \\
\hline 1.29 & 75.96 \\
\hline 1.4 & 70 \\
\hline 1.52 & 64.47 \\
\hline 2 & 49 \\
\hline 2.5 & 39.2 \\
\hline $\begin{array}{c}\text { Nilai Rata- } \\
\text { rata } \Sigma \text { Q ; }\end{array}$ & 81.08 \\
\hline
\end{tabular}


Table III. Hasil Pengukuran Debit Air Basin Terbuka

\begin{tabular}{|l|c|c|c|c|}
\hline No & $\begin{array}{c}\text { Volume } \\
(\mathbf{V})\end{array}$ & $\begin{array}{c}\text { Waktu } \\
(\mathbf{t})\end{array}$ & $\begin{array}{c}\text { Sudut Kran } \\
(\mathbf{(})\end{array}$ & $\begin{array}{c}\text { Debit } \\
(\mathbf{Q})\end{array}$ \\
\hline 1 & 98 liter & 1.28 & $0^{\circ}$ & 76.56 \\
\hline 2 & 98 liter & 1.29 & $10^{\circ}$ & 75.96 \\
\hline 3 & 98 liter & 1.30 & $20^{\circ}$ & 75.38 \\
\hline 4 & 98 liter & 1.31 & $30^{\circ}$ & 74.80 \\
\hline 5 & 98 liter & 1.32 & $40^{\circ}$ & 74.24 \\
\hline 6 & 98 liter & 1.33 & $50^{\circ}$ & 73.68 \\
\hline 7 & 98 liter & 2.32 & $60^{\circ}$ & 42.24 \\
\hline 8 & 98 liter & 2.40 & $70^{\circ}$ & 40.83 \\
\hline 9 & 98 liter & 3.35 & $80^{\circ}$ & 29.25 \\
\hline 10 & 98 liter & 4.10 & $90^{\circ}$ & 23.90 \\
\hline
\end{tabular}




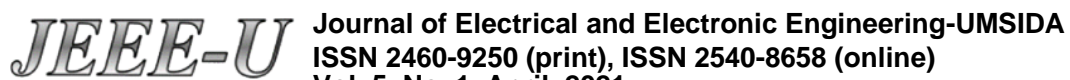

Vol. 5, No. 1, April 2021

Table IV. Hasil Rata-rata Pengukuran Debit Air Basin Terbuka

\begin{tabular}{|c|c|}
\hline Waktu (t) & Debit (Q) \\
\hline 1.28 & 76.56 \\
\hline 1.29 & 75.96 \\
\hline 1.3 & 75.38 \\
\hline 1.31 & 74.8 \\
\hline 1.32 & 74.24 \\
\hline 1.33 & 73.68 \\
\hline 2.32 & 42.24 \\
\hline 2.4 & 40.83 \\
\hline 3.35 & 29.25 \\
\hline 4.1 & 23.9 \\
\hline Nilai Rata-rata $\Sigma$ Q $;$ & 65.21 \\
\hline
\end{tabular}




\section{DAFTAR GAMBAR}

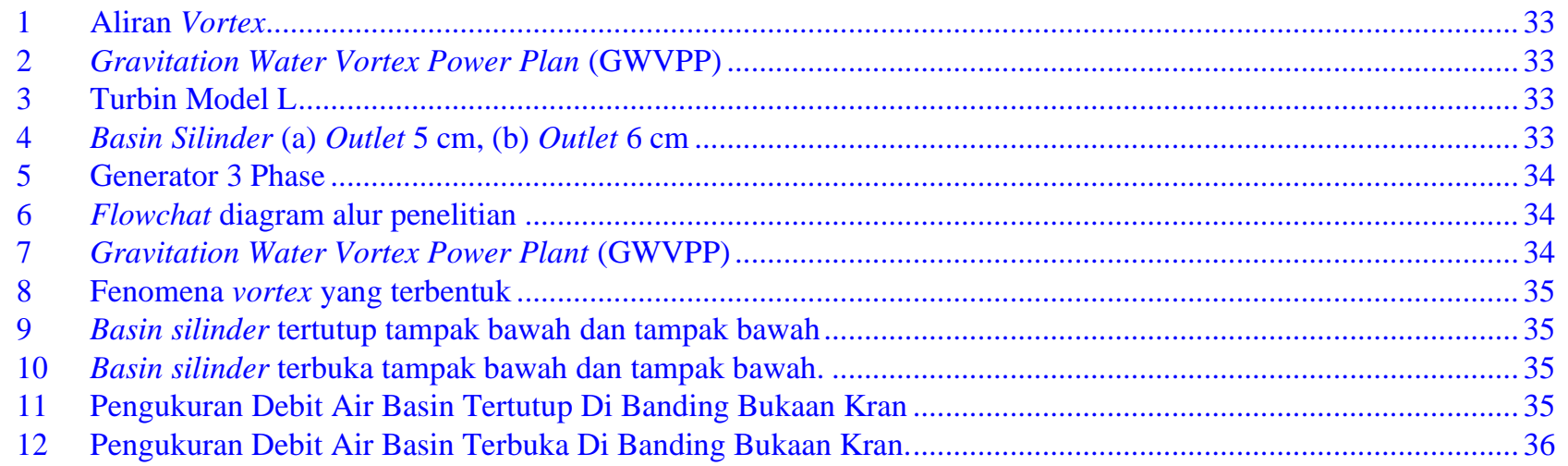




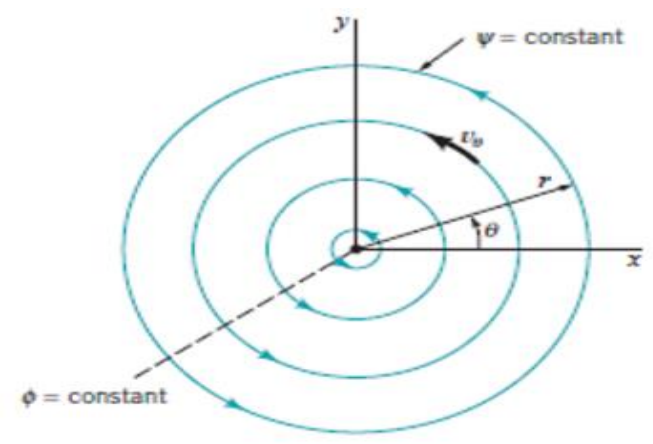

Figure 1. Aliran Vortex

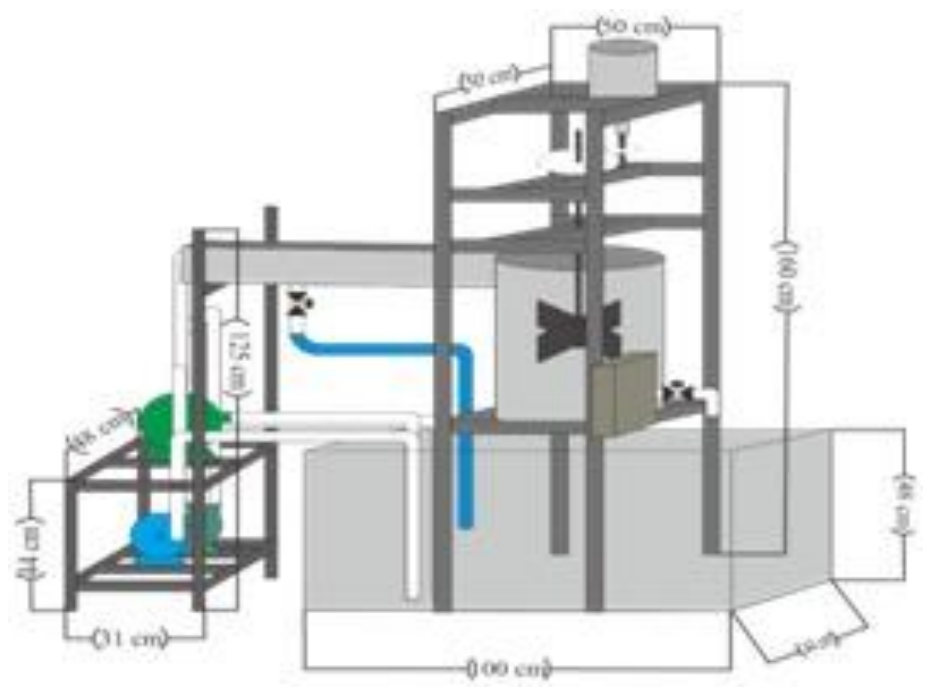

Figure 2. Gravitation Water Vortex Power Plan (GWVPP)

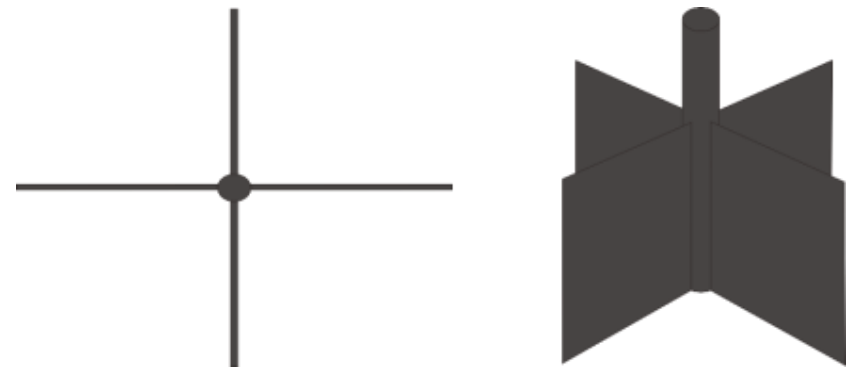

Figure 3. Turbin Model L

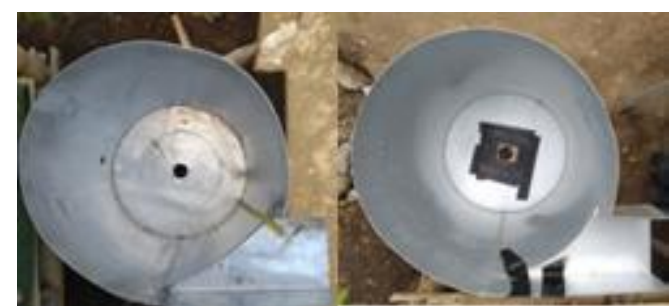

Figure 4. Basin Silinder (a) Outlet $5 \mathrm{~cm}$, (b) Outlet $6 \mathrm{~cm}$ 


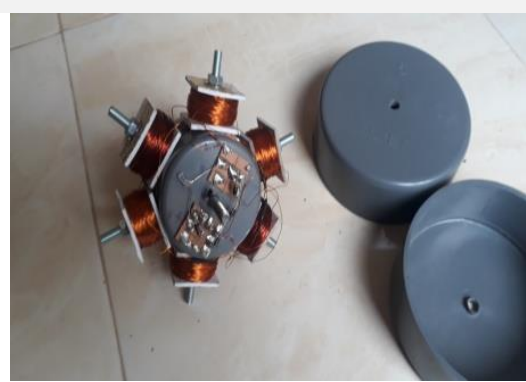

Figure 5. Generator 3 Phase

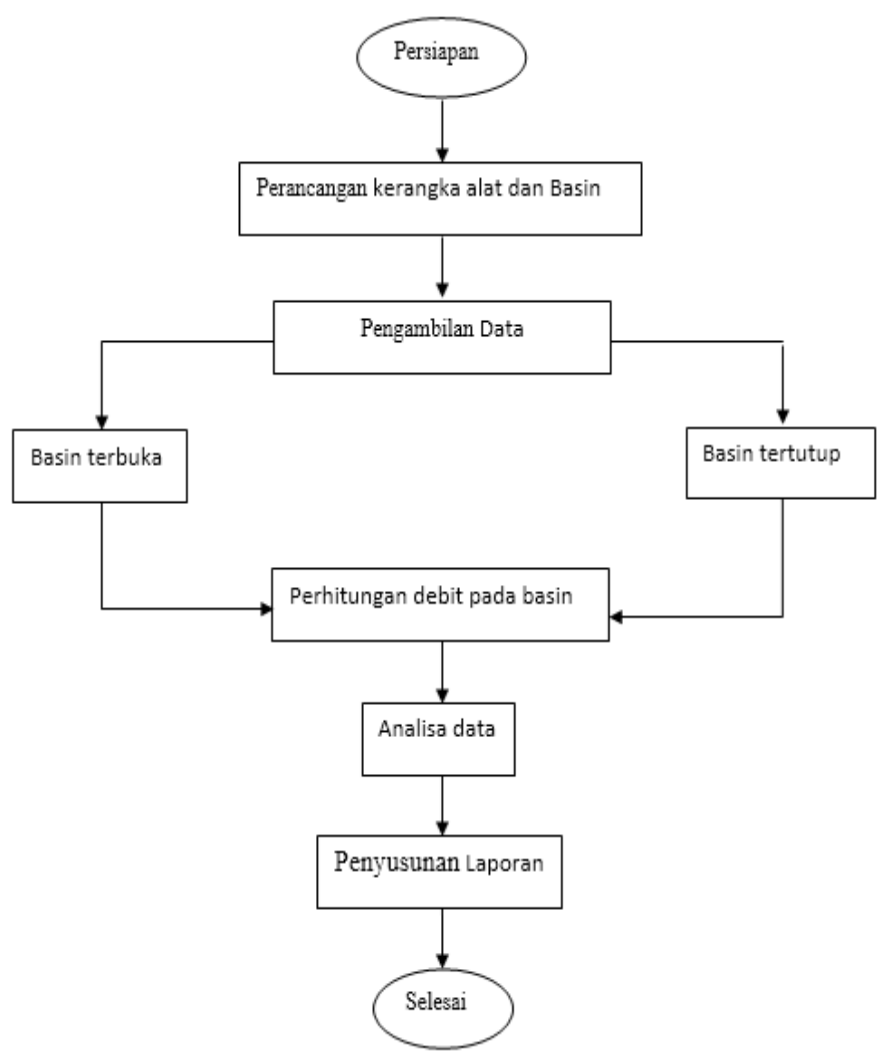

Figure 6. Flowchat diagram alur penelitian

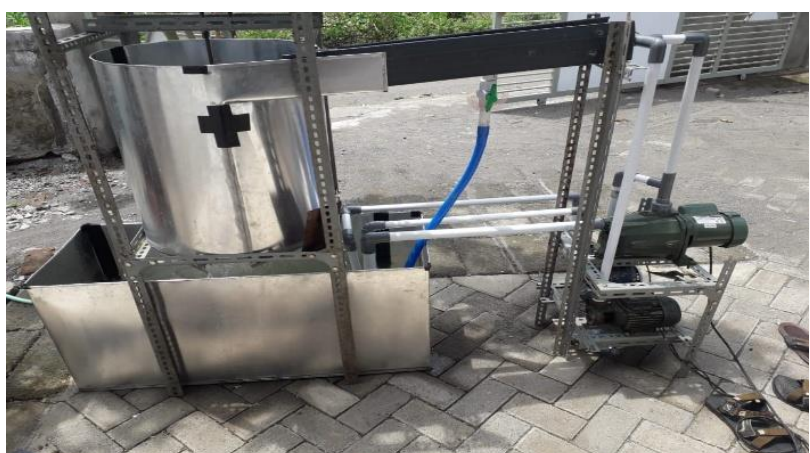

Figure 7. Gravitation Water Vortex Power Plant (GWVPP) 


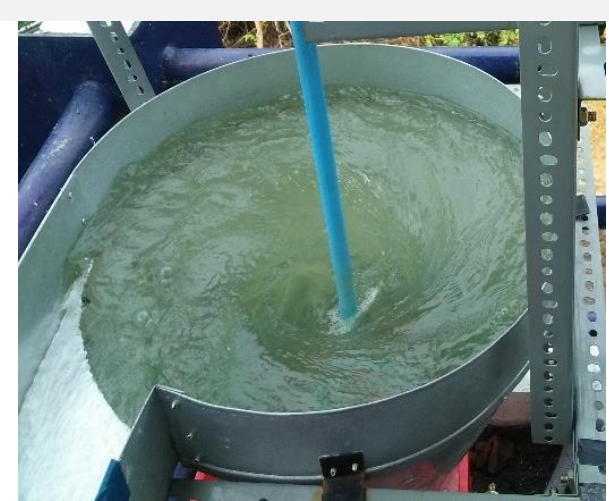

Figure 8. Fenomena vortex yang terbentuk

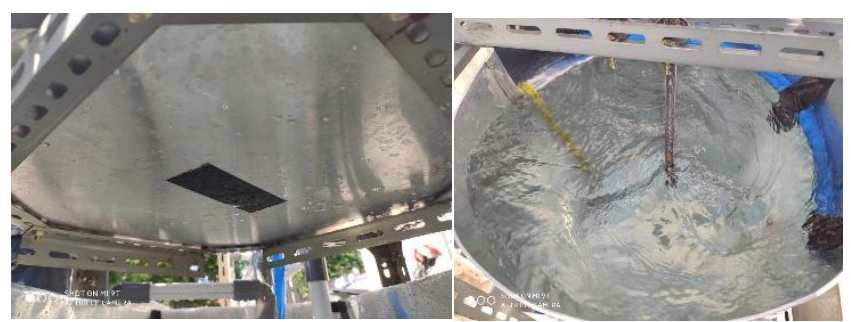

Figure 9. Basin silinder tertutup tampak bawah dan tampak bawah

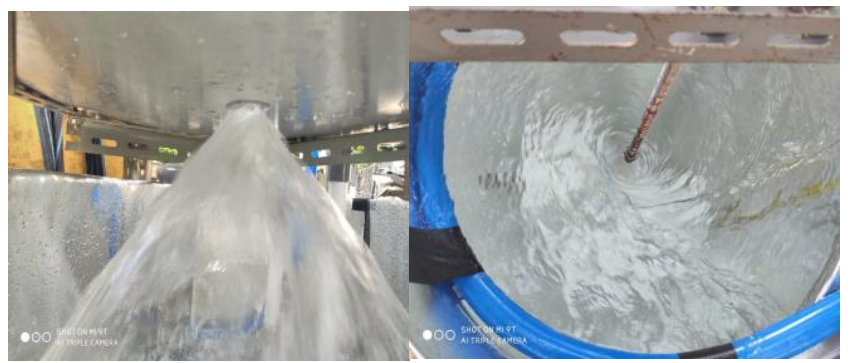

Figure 10. Basin silinder terbuka tampak bawah dan tampak bawah

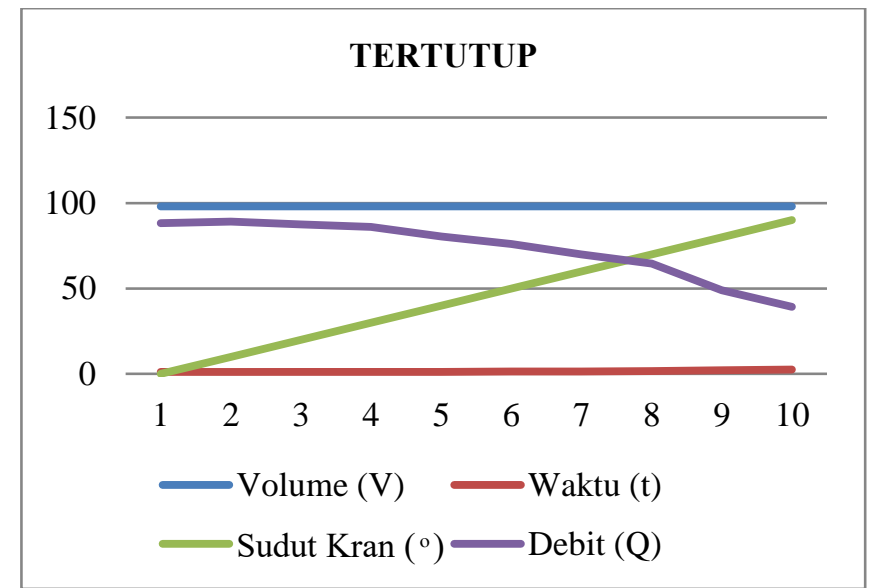

Figure 11. Pengukuran Debit Air Basin Tertutup Di Banding Bukaan Kran 


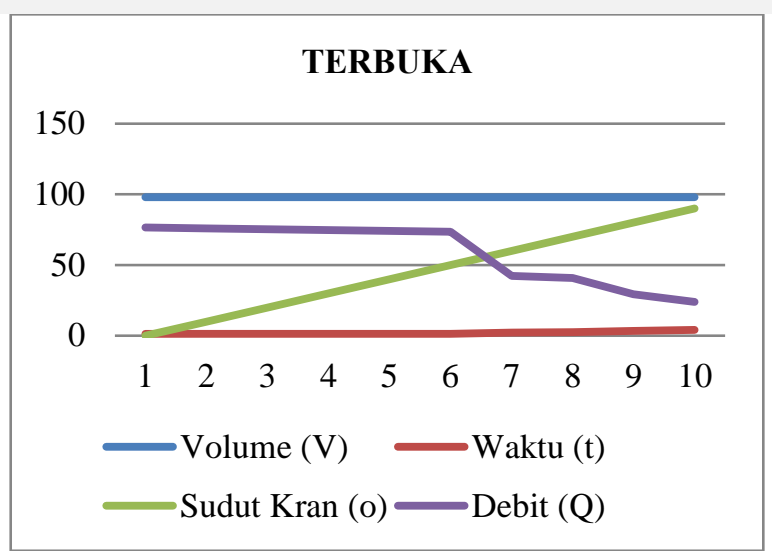

Figure 12. Pengukuran Debit Air Basin Terbuka Di Banding Bukaan Kran. 